\title{
Pengaruh Modifikasi Permainan Monopoli Terhadap Pengetahuan dan Sikap Siswa mengenai Keamanan Makanan Jajanan
}

\author{
Weni Enjelina $^{1 \otimes}$, Asih Febria Ningrum ${ }^{1}$, Zulya $^{1}$ Erda $^{1}$ \\ ${ }^{1}$ Jurusan Kesehatan Lingkungan, Poltekkes Kemenkes Tanjungpinang
}

\section{Info Artikel}

Diterima 11 Maret 2020

Disetujui 11 Maret 2020

Diterbitkan 28 Mei 2020

Kata Kunci:

Monopoli

Pengetahuan

Sikap

Jajanan

e-ISSN:

2613-9219

Akreditasi Nasional:

Sinta 4

Keywords:

Monopoly

Knowledge

Attitude

Snacks

${ }^{凶}$ Coresponding author:
wenienjelina@gmail.com

\begin{abstract}
Abstrak
Latar Belakang: Pengetahuan dan Sikap tentang keamanan makanan mempengaruhi tindakan siswa sekolah dasar dalam memilih makanan jajanan. Permainan monopoli merupakan media edukatif untuk memberikan informasi. Tujuan: untuk mengetahui pengaruh modifokasi permainan monopoli terhadap pengetahuan dan sikap siswa tentang kemanan makanan jajanan. Metode: Penelitian pra eksperimen ini menerapkan desain one group pre test and post test. Subjek penelitian adalah 38 siswa kelas 4 SDN 013 Satu Atap Kota Tanjungpinang. Data pengetahuan dan sikap dikumpulkan menggunakan kuesioner, dan dianalissi secara bivariat menggunakan uji Wilcoxon. Hasil: Peningkatan rerata skor pengetahuan dan sikap siswa dari 7,58 dan 7,55 menjadi 8,26 dan 8,23 Hal ini menunjukkan peningkatan pengetahuan dan sikap yang signifikan, masing-masing sebesar $21 \%(p=0,013)$ dan $31 \%(p=0,002)$. Kesimpulan: Modifikasi permainan monopoli dapat meningkatkan pengetahuan dan sikap siswa sekolah dasar tentang keamanan makanan.
\end{abstract}

\section{Abstract}

Background: Knowledge and attitudes about food safety affect the actions of elementary students in choosing snacks. Monopoly games are a educatif media to provide information. Objective: To know the influence of Modified Monopoly Game onthe knowledge and attitude of elementary student about food security. Method: This pre-experiment research was using one group pre test and post test design. Subject research were 38 students of 4th class in SDN 013 Satu Atap Kota Tanjungpinang.Knowledge and attitude data were collected using a questionnaire and analyzed bivariately using Wilcoxon Test. Results: This research increased average score of student's knowledge and attitude about snack food security from 7,58 and 7,55 to 8,26 and 8,23 . This showed a significant increase in knowledge and attitudesby $21 \%(p=0,013)$ and $31 \%(p=0,002)$. Conclusion: The Modified Monopoly game can increase knowledge and attitude of elementary school about food safety. 


\section{Pendahuluan}

Anak usia sekolah lebih aktif dalam memilih makanan yang disukai. Kebutuhan energi lebih besar karena peningkatan aktifitas fisik seperti berolahraga, bermain, dan sekolah [1]. Kondisi ini mendorong anak usia sekolah mengkonsumsi makanan jajanan, disamping alasan lain seperti tidak sempat makan pagi sebelum ke sekolah dan mendapat uang saku. Terdapat 210 Jenis makanan jajanan yang sering dijajakan di sekolah, diantaranya yaitu bakso, mie, es, jeli dan kue tradisional [2].

Konsumsi Pangan Jajan Anak Sekolah (PJAS) berperan penting dalam memenuhi asupan energi dan gizi anak usia sekolah. Namun PJAS yang tidak aman dan berkualitas justru akan membahayakan kesehatan dan kualitas tumbuh kembang anak [3]. Laporan hasil pengawasan PJAS yang dilakukan Badan Pengawas Obat dan Makanan (BPOM), selama periode 20092016 masih ditemukan PJAS yang tidak memenuhi syarat. Permasalahan PJAS yang ditemukan terutama PJAS yang terkontaminasi cemaran fisik (debu, rambut), kimia (Pengunaan bahan tambahan pangan yang berlebihan) dan mikrobiologi (kurangnya sanitasi dan higiene) [4].

Ada faktor intenal dan ekstrenal yang mempengaruhi pemilihan makanan jajanan siswa. Faktor internal yaitu faktor yang berasal dari siswa itu sendiri meliputi pengetahuan, persepsi, kecerdasan, emosi dan motivasi dari luar, sedangkan faktor eksternal merupakan faktor yang berasal dari luar, seperti peran orang tua, harga PJAS, serta keberadaan kantin di sekolah [1],[5]. Pengetahuan yang masih rendah menjadi salah satu faktor pemilihan makanan jajanan yang tidak aman [6].

Upaya untuk mengurangi paparan anak sekolah terhadap makanan jajanan yang tidak sehat dan tidak aman, perlu dilakukan, salah satu nya dengan promosi keamanan makanan. Materi terkait keamanan makanan jajanan perlu diberikan pada siswa tentang perilaku sehat untuk konsumsi jajanan sekolah [7]. Penyampaian materi pada anak SD dilakukan dengan metode permainan menarik dibandingkan ceramah, karena mempertimbangkan anak usia SD yang aktif dan suka bermain. Tingkat pengetahuan anak SD tentang keamanan makanan jajanan sekolah mengalami peningkatan setelah mendapat penyuluhan dengan menggunakan strategi berbeda (media permainan edukatif ular tangga dan metode ceramah) dibandingkan metode ceramah saja [8].

Intervensi untuk meningkatkan sikap dan perilaku keamanan makanan pada anak sebagai pendidikan sejak dini disampaikan melalui teknik bernyanyi dan bermain, seperti permainan kartu bergambar [9].

Survei pendahuluan di Sekolah Dasar (SD) Negeri 013 Satu Atap Kota Tanjungpinang, dari 45 siswa diketahui bahwa $60 \%$ siswa sarapan disekolah, sehingga kecenderungan untuk jajan di sekolah akan lebih besar. Jenis jajanan yang menjadi pilihan siswa untuk dikonsumsi seperti kerupuk, nasi goreng, nasi lemak, cilok, bakso, es, kue, dan gorengan. Siswa memilih makanan belum berdasarkan pada keamanannya, sehingga peneliti memilih untuk melakukan penelitian di SDN 013 Satu Atap Kota Tanjungpinang.

Tujuan penelitian ini adalah untuk mengetahui apakah ada pengaruh metode permainan monopoli edukatif terhadap pengetahuan dan sikap tentang keamanan makanan jajanan pada siswa SD.

\section{Metode}

Penelitian pra eksperimen ini menerapkan rancangan One Group pre-test and post-test design. Penelitian dilakukan di SDN 013 Satu Atap Kota Tanjungpinang pada Bulan Februari-Maret 2018. Subjek penelitian sebanyak 38 siswakelas IV yang berusia 9-10 tahun. Berdasarkan tahap perkembangan, siswa kelas IV SD berada dalam tahap operasional konkret. Anak telah mampu berpikir secara logis dan fleksibel mengorganisasi benda konkret. Pembelajaran dengan media konkret cocok untuk diterapkan pada siswa SD kelas IV karena sesuai dengan karakteristik perkembangan mereka [10].

Tingkat pengetahuan dan sikap siswa diukur menggunakan kuisioner yang berisi 20 soal tentang keamanan pangan. Permainan yang digunakan berupa modifikasi dari permainan monopoli yang dicetak dengan desain gambar keamanan makanan. Papan monopoli dibuat dalam bentuk spanduk besar, sehingga siswa bisa langsung berperan sebagai bidaknya. Spanduk papan monopoli terdiri dari satu kotak untuk start, satu kotak untuk rumah sakit, dan kotak yang lain diberi gambar tentang keamanan makanan.

Informasi yang pada papan monopoli ditampilkan dalam bentuk gambar tentang jenis wadah kemasan makanan yang berbahaya seperti styrofoam dan koran bekas, serta yang aman digunakan seperti plastik, gelas, kaleng food grade, serta ciri kerusakan makanan, seperti penyok, kembung, adanya vektor pada makanan seperti semut dan lalat, ciri makanan dengan bahan tambahan makanan yang berlebihan, serta ciri lokasi atau tempat jualan yang bersih dan sehat. Bentuk spanduk papan monopoli disajikan pada gambar 1 . 


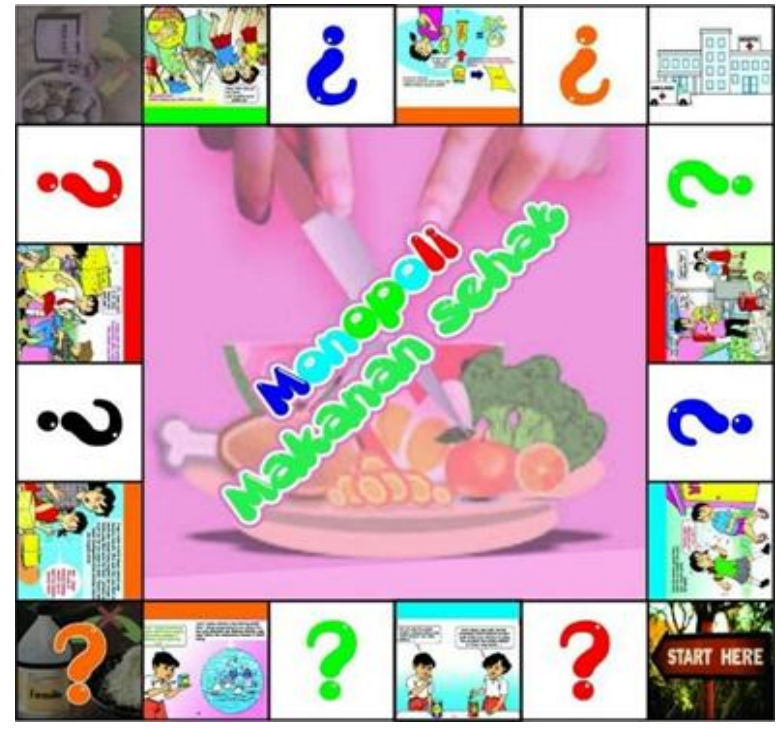

Gambar 1. Papan Permainan Monopoli

Penelitian diawali dengan melakukan pre-test pengetahuan dan sikap. Setelah itu, dilakukan permainan edukasi monopoli. Prosedur permainan monopoli diawali dengan membagikan permen sebagai pengganti uang dari permainan monopoli pada umumnya. Setiap kelompok menunjuk satu orang dari anggotanya untuk menjadi bidak atau pion. Siswa yang menjadi bidak berdiri pada kotak start. Putaran pertama, peserta hanya berlomba untuk melewati start. Putaran kedua, kelompok yang bidaknya menempati kotak dengan simbol tanda tanya, maka kelompok tersebut harus menjawab sebuah pertanyaan tentang keamanan makanan yang diajukan oleh peneliti. Jika jawaban benar maka kelompok itu akan diberikan sebuah permen, dan jika salah kelompok itu akan memberikan sebuah permen.

Kelompok yang bidaknya menempati kotak bergambar, siswa yang menjadi bidaknya harus membacakan tulisan-tulisan yang ada pada gambar tesebut. Tulisan yang ada pada kotak-kotak bergambar tersebut merupakan suatu informasi tentang keamanan makanan. Kelompok yang bidaknya menempati kotak bergambar rumah sakit, maka kelompok tersebut harus memberikan 3 buah permennya kepada peneliti sebagai biaya pengobatan. Kelompok dengan permen terbanyak yang akan menjadi pemenangnya. Permainan dilaksanakan selama 45 menit, sebanyak tiga kali putaran. Tahap akhir penelitian dilakukan post-test untuk mengetahui pengetahuan dan nilai sikap siswa setelah mendapat perlakuan permainan edukatif. Analisis data pengetahuan dan sikap siswa dilakukan dengan uji kenormalan distribusi data, dan dilanjutkan uji Wilcoxon Signed Rank karena tidak berdistribusi normal.

\section{Hasil}

Sampel yang menjadi subjek penelitian adalah siswa sekolah dasar kelas 4 SD. Karakteristik responden sebagian besar $(68 \%)$ responden berada pada usia 9-10 tahun dan sebagian besar (53\%) berjenis kelamin laki-laki. Pengukuran tingkat pengetahuan dan sikap responden menggunakan instrumen kuesioner tentang keamanan makanan jajanan pada sebelum dan sesudah diberikan penyuluhan melalui permainan edukatif. Data hasil pengetahuan sebelum penyuluhan permainan edukatif disajikan pada Tabel 1 .

Tabel 1. Tingkat Pengetahuan dan Sikap Siswa Sebelum dan Sesudah Permainan Edukasi Monopoli

\begin{tabular}{lcccccc}
\hline Variabel & \multicolumn{3}{c}{ Sebelum Permainan } & \multicolumn{3}{c}{ Setelah Permainan } \\
\cline { 2 - 7 } & Mean & Min & Maks & Mean & Min & Maks \\
\hline Pengetahuan & 7,58 & 5 & 10 & 8,26 & 6 & 10 \\
\hline Sikap & 7,55 & 4 & 10 & 8,23 & 6 & 10 \\
\hline
\end{tabular}

Berdasarkan tabel 1 menunjukkan bahwa setelah dilakukan permainan edukasi monopoli, pengetahuan siswa mengalami peningkatan yaitu dari nilai rata-rata 7,58 meningkat menjadi 8,26 . Begitu juga sikap mengalami peningkatan dari 7,55 menjadi 8,23 . Pengetahuan dan sikap siswa dinilai dari pertanyaan yang diajukan pada setiap kotak monopoli dengan jumlah pertanyaan 10 pertanyaan untuk pengetahuan dan 10 pertanyaan untuk sikap.

Tabel 2. Pengetahuan tentang Makanan Jajanan Sebelum dan Sesudah Intervensi

\begin{tabular}{lcccc}
\hline & \multicolumn{3}{c}{ Jawaban Intervensi } \\
\cline { 2 - 5 } Pernyataan & \multicolumn{2}{c}{ Sebelum } & \multicolumn{2}{c}{ Setelah } \\
\cline { 2 - 5 } & Benar & $\mathbf{( \% )}$ & Benar & $\mathbf{( \% )}$ \\
\hline Jenis Makanan Jajanan & & & & \\
$\quad$ Contoh makanan jajanan & 38 & 100 & 38 & 100 \\
\hline Wadah/Kemasan makanan Jajanan & & & & \\
$\quad$ Wadah yang bersih dan aman & 36 & 95 & 35 & 92 \\
\hline Kerusakan makanan jajanan & & & & \\
$\quad$ Ciri kemasan sehat dan aman & 31 & 82 & 36 & 95 \\
$\quad$ Kemasan sudah rusak/penyok & 36 & 95 & 37 & 97 \\
$\quad$ Contoh kemasan yang rusak & 9 & 23 & 20 & 53 \\
\hline Vektor pembawa penyakit & & & & \\
$\quad$ Jajanan dikerubungi semut & 37 & 97 & 36 & 95 \\
$\quad$ Makanan telah dihinggapi lalat & 8 & 21 & 16 & 42 \\
\hline Bahan Tambahan Makanan & & & & \\
$\quad$ Makanan berwarna terang & 30 & 79 & 33 & 87 \\
$\quad$ Minuman dengan pemanis buatan & 25 & 66 & 27 & 71 \\
\hline Tempat/Lokasi Jualan & & & & \\
$\quad$ Lokasi jualan makanan bersih & 38 & 100 & 37 & 97 \\
\hline
\end{tabular}


Berdasarkan tabel 2 menunjukkan bahwa jawaban paling sedikit benar adalah tentang bahaya makanan yang dihinggapi lalat sebanyak $21 \%$, namun setelah dilakukan intervensi tentang bahaya makanan yang dihinggapi lalat meningkat menjadi $42 \%$.

Tabel 3. Sikap tentang Makanan Jajanan Sebelum dan Sesudah Intervensi

\begin{tabular}{llccc}
\hline & \multicolumn{4}{c}{ Jawaban Intervensi } \\
\cline { 2 - 6 } Pernyataan & \multicolumn{2}{c}{ Sebelum } & \multicolumn{3}{c}{ Setelah } \\
\cline { 2 - 6 } & Benar & $\mathbf{( \% )}$ & Benar & $(\%)$ \\
\hline Wadah/Kemasan makanan Jajanan & & & & \\
$\quad$ Jajanan dengan wadah tertutup & 37 & 97 & 38 & 100 \\
\hline Jajanan bungkusnya menarik & 18 & 47 & 26 & 68 \\
\hline Bungkus rusak boleh dimakan & 36 & 95 & 37 & 97 \\
\hline Kerusakan makanan jajanan & & & & \\
$\quad$ Jajanan tidak busuk atau bau & 33 & 87 & 34 & 89 \\
$\quad$ Makanan baru dan tidak bau & 37 & 97 & 36 & 95 \\
\hline Bahan Tambahan Makanan & & & & \\
$\quad$ Jajanan berwarna mencolok & 34 & 89 & 36 & 95 \\
$\quad$ Minuman pemanis buatan & 22 & 58 & 27 & 71 \\
\hline$\quad$ Makanan dengan pengawet & 17 & 45 & 24 & 63 \\
\hline Tempat/Lokasi Jualan & & & & \\
$\quad$ Jajanan tempat yang bersih & 38 & 100 & 37 & 97 \\
$\quad$ Jajanan yang harganya murah & 15 & 39 & 22 & 58 \\
\hline
\end{tabular}

Berdasarkan tabel 3 menunjukkan bahwa sikap siswa sebelum intervensi masih rendah tentang kemasan makanan sebesar $47 \%$, pemanis buatan $58 \%$, pengawet $45 \%$ dan prioritas harga $39 \%$. Setelah intervensi meningkat tentang kemasan makanan sebesar $68 \%$, pemanis buatan $71 \%$, pengawet $63 \%$ dan prioritas harga $58 \%$.

Tabel 4. Pengaruh Permainan Edukasi Monopoli terhadap Pengetahuan dan Sikap Siswa

\begin{tabular}{lccc}
\hline Variabel & Mean & SD & $\boldsymbol{p}$ \\
\hline $\begin{array}{l}\text { Pengetahuan } \\
\text { Pre test }\end{array}$ & 7,58 & 1,407 & \\
$\quad$ Pos test & 8,26 & 1,173 & 0,0001 \\
\hline Sikap & & & \\
$\quad$ Pre test & 7,55 & 1,537 & 0,008 \\
$\quad$ Post test & 8,23 & 1,223 & \\
\hline
\end{tabular}

Berdasarkan tabel 4 menunjukkan bahwa ada pengaruh permainan edukatif terhadap pengetahuan dan sikap keamanan makanan jajanan pada siswa SDN 013 Satu Atap Kota Tanjungpinang.

\section{Pembahasan}

Siswa yang menjadi subjek penelitian berusia 9 s/d 14 Tahun dengan rata-rata berusia 10 tahun. Metode pembelajaran yang direkomendasikan pada anak usia 6 s/d 11 Tahun yaitu metode chungking (menggunakan gambar untuk mudah mengingat), kolaboratif dan menggunakan alat peraga sehingga anak bisa berpartisipasi secara aktif. Anak usia ini berada dalam tahap operasional konkrit yaitu aktivitas mental yang difokuskan pada objek-objek peristiwa nyata atau konkrit, sehingga edukasi dengan metode action dimana anak berperan langsung akan lebih mudah diingat dibandingkan dengan metode ceramah dimana siswa duduk hanya melihat dan mendengarkan [11].

Permainan monopoli sesuai dengan metode pembelajaran tersebut. Media yang digunakan dalam bentuk gambar sehingga mudah diingat siswa. Permainan dilakukan secara berkelompok dengan semua anggota kelompok berpartisipasi aktif dalam permainan, baik yang berperan sebagai bidak, maupun penjawab pertanyaan. Pada permainan apabila siswa menempati gambar yang bertanda silang dan merupakan larangan, maka siswa akan pindah ke kotak bergambar rumah dan wajib memberikan sejumlah permen kepada kelompok lawan, sebaliknya apabila siswa menempati gambar bertanda centang atau berupa prilaku sehat, maka kelompok tersebut mendapatkan permen dari kelompok lawan.

Pengetahuan siswa tentang ciri kerusakan makanan jajanan, bahaya vektor lalat dan pemanis buatan. Ciri makanan jajanan yang sudah rusak atau tidak layak dimakan sebelum dilakukan intervensi masih rendah. Siswa sebelumnya hanya 9 orang menjawab benar tentang ciri kerusakan makanan jajanan, meningkat menjadi 20 orang setelah dilakukan intervensi. Setelah intervensi, siswa menjawab benar bahwa makanan yang rusak bisa diketahui dengan keberadaan jamur dan bakteri berdasarkan gambar pada monopoli yang menampilkan roti yang terdapat jamur dan bakteri yang apabila dimakan menyebabkan muntah dan diare. Makanan yang telah terkontaminasi jamur atau bakteri, walaupun masih terlihat utuh dan tidak berbau busuk tidak diizinkan untuk dikonsumsi, karena beresiko menyebabkan diare hingga keracunan [6].

Sebagian siswa juga sebelumnya masih menjawab bahwa makanan yang dihinggapi lalat, selama tidak dikerubungi masih boleh dikonsumsi. Setelah intervensi jumlah siswa yang menjawab benar meningkat. Perubahan jawaban siswa diasumsikan berdasarkan gambar pada permainan monopoli yang memperlihatkan lalat yang berada di kotoran dan sampah yang kemudian hinggap pada makanan. Pada permainan apabila siswa menempati gambar yang bertanda silang dan merupakan larangan, maka siswa 
wajib memberikan sejumlah permen kepada kelompok lawan. Selain ciri kerusakan dan vektor lalat, pengetahuan siswa tentang pemanis buatan juga meningkat. Gambar pada permainan monopoli yang memperlihatkan gambar seorang anak yang membawa botol minuman sendiri dan menghindari minuman kemasan merupakan prilaku sehat yang harus diikuti oleh siswa.

Sikap siswa sebelum intervensi masih rendah tentang kemasan makanan, pemanis buatan, pengawet dan prioritas harga. Siswa masih mengedepankan kemasan yang menarik, rasa yang enak dan harga yang murah dibandingkan segi kesehatannya, seperti penggunaan pemanis dan pengawet buatan. Akan tetapi setelah permainan edukatif monopoli jawaban benar siswa meningkat, diasumsikan bahwa siswa memahami dan menyetujui untuk menjadikan kesehatan makanan sebagai prioritas utama dalam pemilihan makanan yang akan dikonsumsi.

Perubahan sikap siswa ini didasarkan pada gambar-gambar pada permainan monopoli. Salah satu gambar permainan monopoli memperlihatkan seorang anak yang mengkonsumsi minuman yang dikemas menarik dan murah, akan tetapi tidak memiliki label BPOM. Siswa yang sampai pada kotak tersebut akan mendapat penjelasan dan selanjutnya pindah ke kotak rumah sakit. Kelompok siswa tersebut kemudian memberikan sejumlah permen pada kelompok lawan sesuai catatan pada kotak. Nilai sikap responden setelah diberikan penyuluhan dengan metode permainan edukatif sebagian besar meningkat karena responden sudah bisa menangkap seluruh hal positif yang mereka dapatkan dari intervensi. Setelah pengetahuan mereka cukup, emosional mereka bereaksi dengan stimulus yang ada [7].

Ada pengaruh permainan edukatif terhadap pengetahuan dan sikap keamanan makanan jajanan pada siswa SDN 013 Satu Atap Kota Tanjungpinang. Peningkatan pengetahuan siswa merupakan hasil dari pemberian informasi dengan metode permainan edukatif monopoli. Permainan ini sudah dimodifikasi agar bisa dimainkan secara berkelompok. Pemberian penyuluhan dengan metode ini terletak pada gambar di papan monopoli dan pertanyaan-pertanyaan tentang keamanan makanan.

Pengetahuan sebagian besar diperoleh melalui indera penglihatan dan indera pendengaran [12]. Pada metode permainan ini alat indera yang paling berperan adalah indera penglihatan. Permainan ini dapat meningkatkan perhatian, konsentrasi dan imajinasi anak kemudian anak tersebut diharapkan mulai belajar menerapkan hal yang dipelajari sehingga akhirnya dapat membentuk pengetahuan dan sikap yang baik dalam pemilihan makanan jajanan yang aman.

Permainan edukasi lain yaitu ular tangga juga sudah dikembangkan dan terbukti dapat lebih meningkatkan pengetahuan siswa [13]. Ular tangga yang dibuat dimodifikasi dengan mengubah tulisan dalam kotak, kemudian tetap dimainkan seperti biasa. Permainan monopoli pada penelitian ini tidak hanya dimodifikasi bentuk dan tulisan di dalam kotak saja, akan tetapi dibuat besar dan dimainkan secara langsung dengan siswa sebagai bidak nya. Permainan ini mengajak siswa beraksi langsung, sehingga lebih mengingat isi dari masing-masing kota yang berkaitan dengan kemanan makanan jajanan.

Sikap adalah pandangan, pendapat, tanggapan ataupun penilaian dan juga perasaan seseorang terhadap stimulus atau objek yang disertai dengan kecenderungan untuk bertindak [14]. Pada penelitian ini stimulus yang digunakan kepada responden adalah metode permainan edukatif monopoli. Hal itu lah yang mendukung terjadinya perubahan sikap pada sebagian besar responden. Penelitian ini sejalan dengan hasil penelitian tentang penggunaan alat permainan edukatif ular tangga untuk meningkatan pengetahuan dan sikap tentang buah dan sayur menunjukkan bahwa pendidikan kesehatan menggunakan alat permainan edukatif ular tangga memberikan pengaruh signifikan terhadap peningkatan pengetahuan [13].

Perubahan sikap pada dasarnya dipengaruhi oleh faktor pengetahuan dan keyakinan/kepercayaan yang didapatkan dari hasil penginderaan, yang salah satunya didapatkan dengan proses belajar. Banyak faktor yang mempengaruhi orang untuk bersikap yaitu pengalaman pribadi, kebudayaan, orang lain yang dianggap penting, media massa, institusi atau lembaga pendidikan dan lembaga agama, serta faktor emosi dalam diri individu tersebut [15]. Ketidaktahuan tentang bahan makanan dapat menyebabkan pemilihan makanan yang salah dan rendahnya pengetahuan akan menyebabkan sikap masa bodoh terhadap makanan tertentu.

Pengetahuan yang rendah dapat menyebabkan sikap negatif dari seseorang. Sikap seseorang akan mempengaruhi pengetahuan yang dimilikinya. Responden yang memiliki sikap positif kemungkinan memiliki pengetahuan yang lebih baik tentang makanan jajanan dibandingkan dengan responden yang memiliki sikap negatif [16].

\section{Kesimpulan}

Permainan monopoli yang dimodifikasi dapat meningkatkan pengetahuan dan sikap tentang 
keamanan makanan jajanan pada siswa tentang ciri kerusakan makanan jajanan, kemasan makakanan, bahaya vektor lalat, pemanis buatan dan prioritas harga. Peningkatan pengetahuan dan sikap yang signifikan. Permainan ini dapat menjadi salah satu media yg baik dalam intervensi pengetahuan dan sikap siswa terkait makanan jajanan di sekolah.

\section{Ucapan Terima Kasih}

Peneliti mengucapkan terima kasih kepada Kepala Sekolah SD Negeri 013 Satu Atap Kota Tanjungpinang atas izinnya beserta guru dan siswa SD atas kerjasama nya yang baik.

\section{Daftar Pustaka}

[1] Alhidayati, A.S.Efendi, A.Hakim. FaktorFaktor Yang Berhubungan Dengan Pemilihan Makanan Jajanan Sehat Pada Siswa Sekolah Dasar Negeri 145 Pekanbaru Tahun 2017. Collaborative Medical Journal (CMJ). 2018; 1 (2): 45-57

[2] Khusna N, H.B. Setiaji, Z. Sahli. Pengaruh Penyuluhan Tentang Jajanan Sehat Terhadap Pengetahuan Dan Sikap Anak Usia Sekolah Dasar. Jurnal Kesehatan. 2014; 5 (1): DOI: http://dx.doi.org/10.26630/jk.v5i1.64

[3] BPOM RI. Kampanye akbar Ayo Sadar Makanan Aman (ASPA) wujudkan derajat kesahatan yang optimal [Internet]. 2017 [sitasi 2 Januari 2018]. Dikutip dari: http://bpom.go.id

[4] Syarifah P. BPOM: Masih Banyak Jajanan Sekolah Kurang Bersih [Internet]. 27 April 2017 [cited 2018 Jan 2]. Dikutip dari: http://m.liputn6.com/

[5] Notoatmojo S. Kesehatan Masyarakat Ilmu dan Seni. Jakarta: Rineka Cipta. 2011.

[6] Warlenda, S.V, Desnovianti. Faktor-Faktor Yang Berhubungan Dengan Praktek Pemilihan Makanan Jajanan Di Sekolah Dasar Negeri 29 Pekanbaru Tangkerang Selatan Bukit Raya Tahun 2017. Jurnal Photon; 2018 : 8 (2); 95-100

[7] Triwijayati A, Etsa AS, Yudi S, Maria LL.Anak Dan Jajanan Sekolah: Program Pemberdayaan Kesehatan Anak Sekolah Dalam Perspektif Pemerintah Daerah. Jurnal MKMI. 2016; $12 \quad$ (3); $\quad$ DOI: http://dx.doi.org/10.30597/mkmi.v12i3.1078
[8] Putri Aprina Ria. Perbedaan Pengetahuan Anak Sekolah Dasar tentang Keamanan Makanan Jajanan Sekolah Setelah Mendapat Penyuluhan dengan Menggunakan Strategi Berbeda (Media Permainan Edukatif Ular Tangga dan Metode Ceramah) di SD N Soropadan Karangasem Surakarta [Thesis]. Universitas Muhammadiyah Surakarta; 2013. Available from: http://eprints.ums.ac.id/id/eprint/27258

[9] Eri V, Sapja A, Kusnandar. Pengaruh Teknik Bernyanyi dan Permainan Kartu Bergambar terhadap Sikap dan Perilaku Gizi pada Anak Taman Kanak-Kanak. Jurnal MKMI. 2018; 14 (2); DOI: http://dx.doi.org/10.30597/mkmi.v14i2.3884

[10] PGSDblog. Karakteristik Siswa Anak Kelas IV SD [Internet]. Persatuan Guru SD. 2017. Available from: https://pgsdblog.com

[11] Syah, Muhibbin. Psikologi Pendidikan dengan Pendekatan Baru. Bandung: Remaja Rosdakarya. 2016

[12] Notoatmodjo S. Promosi Kesehatan dan Perilaku Kesehatan. Jakarta: Rineka Cipta. 2012.

[13] Irma Handayani, Zulhaida Lubis Eya. Pengaruh Penyuluhan Dengan Media Permainan Ular Tangga Terhadap Pengetahuan Tentang Buah Dan Sayur Pada Siswa Mts-S Almanar Kecamatan Hamparan Perak. JUMANTIK. 2018;3(1).

[14] Notoatmojo S. Pendidikan dan Perilaku Kesehatan. In: Rineka Cipta. 2003.

[15] Saifuddin Azwar. Sikap Manusia: Teori dan Pengukurannya. 2013.

[16] Febryanto, M.A.B. Hubungan Antara Pengetahuan Dan Sikap Dengan Perilaku Konsumsi Jajanan Di Mi Sulaimaniyah Jombang. Jurnal Keperawatan Muhammadiyah; 2016: 1(1) : 7-17 